\title{
Crimped and Hooked End Steel Fibre Impacts on Self Compacting Concrete
}

\author{
Mukilan K, Rameshbabu C , Chithambar Ganesh A
}

\begin{abstract}
Self-compacting concrete is gaining importance in recent years due to its highest versatility in replacing compacting equipment and there by reducing the constructional flaws. The only limitation of SCC of compromising with strength has been challenged by the addition of steel fibers in this paper. In this research work two types of steel fibers such as crimped type and hook end type are utilized in various proportions such as $0.4 \%, 0.8 \%$, $1.0 \%$ and $1.25 \%$. SCC mandatory tests such as Flowing ability, filling ability and passing ability were determined and then the mechanical properties such as compressive strength and split tensile strength have been determined. Results show the unique variation with reference to the different type of fiber and different volume of fiber. This unleashes a lot of scope in the field of Fiber reinforced Self compacting concrete
\end{abstract}

Keywords : Fibre Reinforced SCC,Self Compacting Concrete Steel fibre.

\section{INTRODUCTION}

$\mathrm{S}_{\text {elf-compacting concrete(SCC) is a special type of concrete }}$ that does not need to be consolidated through external means [1]. This special type of concrete consolidates itself and hence helps to reduce plenty of constructional flaws that arises due to improper compaction [3]. Owing to this property this concrete gained a lot of attraction in recent years [4]. This type of concrete eliminates problems due to bleeding and segregation to a great extent [10]. Flowing ability and passing ability determine the basic requirement of SCC [5]. In spite of many advantages, there are some limitations of SCC like there are no global standard for SCC and also some times the strength parameters are not met up to the standards for the proposed mix designs [2] [4]. Fiber reinforced concrete is one of the major development in the contemporary [8]. In this type of concrete, fibrous material augmented in to the concrete adds the structural integrity of concrete [12]. These fibers are of both natural and artificial origin [11]. There are plenty of fibers available like palm, steel, glass, polypropylene etc. These fibers tend to increase the engineering properties like compressive strength, split tensile strength, flexural strength and post cracking behavior [6]. This unleashes a lot of scope to be utilized in SCC [1].

An effort can be made by introducing fibers in to the self-compacting concrete [14]. In this study steel fibers have

Revised Manuscript Received on December 5, 2019

*Mukilan K, Department of Civil Engineering, Kalasalingam Academy of Research and Education Email: mukicivil@gmail.com

Rameshbabu C, Department of Civil Engineering, Kalasalingam Academy of Research and Education Email: babussr@gmail.com

Chithambar Ganesh A, Department of Civil Engineering, Kalasalingam Academy of Research and Education Email babussr@gmail.com been introduced in to the SCC in various proportions such as $0.4 \%,(31.4 \mathrm{~kg} / \mathrm{m} 3) 0.8 \%(62.4), 1.0 \%$ (78) and $1.25 \%(156)$ and investigated. Also fly ash was introduced in addition to cement. Initially fresh properties were examined and tests were conducted to verify the requirements of SCC with the inclusion of steel fibers [16].Later mechanical properties were found out for the mixes that comply with the SCC standards [20].

\section{MATERIALS}

In this study Fiber reinforced SCC is made of flyash, cement, fine aggregate, coarse aggregate, super plasticizer and water. The various properties of the materials used are listed below.

\section{A. Fly ash}

Fly ash of class F type is used. Specific gravity of fly ash is found to be 2.3 using pycnometer test.

\section{B. Cement}

Ordinary Portland Cement of grade 53 is chosen for this study. Specific gravity of cement was ascertained as 3.15 using pycnometer apparatus.

\section{Fine Aggregate}

Locally available river sand was used for the experiment. Specific gravity of fine aggregate was found to be 2.55 . Fineness modulus was found to be 4.57 .

\section{Coarse Aggregate}

Aggregate size used in the experiment varies between 12 to $20 \mathrm{~mm}$. Specific gravity of coarse aggregate was found to be 2.82

\section{E. Super Plasticizer}

FOSROC Conplast sp430 conforming to IS 9103-1999 and IS $2645-1975$ is used as the super plasticizer to improve workability and increase flow ability.

\section{F. Water}

Ordinary portable water was used for the experiment. $\mathrm{pH}$ value of the water was 7.18 and hardness value was $275 \mathrm{mg} / \mathrm{l}$ of $\mathrm{CaCO} 3$.

\section{Methodology}

All the materials are proportioned based upon the reference mix [22] and are mixed in a mixer. At first coarse aggregate and fine aggregate are mixed followed by the addition of flyash $50 \mathrm{~kg} / \mathrm{m}^{3}$ and cement [5]. Water, super plasticizer of 5 litre $/ \mathrm{m}^{3}$ and steel fibers of aspect ratio 50 are then added in to the mixer. It is mixed well for about 3 to 5 minutes [9].

Mandatory tests for SCC such as flow ability, filling ability and passing ability were determined initially using L- Box test, V funnel test and slum flow test [11].

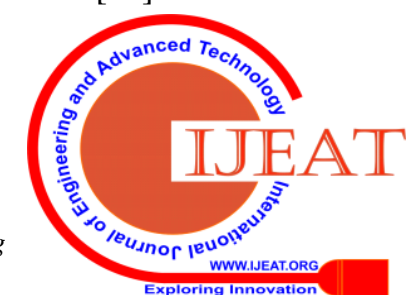


The mixes which pass the initial requirements pass on to the second mechanical properties test such as compressive strength using cubes, cylinders and split tensile strength using cylinder [7].

\section{RESULTS AND DISCUSSION}

\section{A. Slump Flow Test}

The slump flow test is used to assess the horizontal flow of concrete in the absence of obstruction. The test was performed and the readings are tabulated in table I.

Table I : Slump Flow Test

\begin{tabular}{|c|c|c|}
\hline MIX & $\begin{array}{c}\text { SLUMP CONE } \\
\text { TEST } \\
(\mathbf{m m})\end{array}$ & $\begin{array}{c}\text { EFNARC GUIDELINES FOR } \\
\text { SLUMP CONE TEST } \\
(\mathbf{m m})\end{array}$ \\
\hline $\begin{array}{c}\text { SCC1 } \\
(0.4 \%)\end{array}$ & 625 & \\
\hline $\begin{array}{c}\text { SCC } 2 \\
(0.8 \%)\end{array}$ & 550 & \multirow{2}{*}{$550-800$} \\
\hline $\begin{array}{c}\text { SCC } 3 \\
(1.0 \%)\end{array}$ & 530 & \\
\hline $\begin{array}{c}\text { SCC4 } \\
(1.25 \%)\end{array}$ & 610 & \\
\hline
\end{tabular}

From Table I ,it is inferred that all the observed readings are found to be in accordance with the EFNARC guidelines.

\section{B. V-Funnel test}

$\mathrm{V}-$ Funnel test was performed to find out the filling ability of SCC. The readings are tabulated in Table II.

Table II :V - Funnel Test

\begin{tabular}{|c|c|c|}
\hline MIX & $\begin{array}{c}\text { V - FUNNEL } \\
\text { TEST } \\
\end{array}$ & $\begin{array}{c}\text { EFNARC GUIDELINES } \\
\text { FOR }\end{array}$ \\
\hline SCC1 & 6 & \\
\hline SCC2 & 8 & \\
& V-FUNNEL TEST (S) \\
\hline SCC3 & 12 & \\
& & \\
\hline SCC4 & 7 & \\
\hline
\end{tabular}

From Table II it is inferred that all the observed readings are found to be in accordance with the EFNARC guidelines

\section{L Box Test}

L- Box test was performed to assess the passing ability of SCC. The readings are tabulated in Table III.
Table III : L - Box Test

\begin{tabular}{|c|c|c|}
\hline MIX & $\begin{array}{c}\text { L- BOX TEST } \\
\text { (h2/h1) }\end{array}$ & EFNARC GUIDELINES FOR \\
& L- BOX TEST $(\mathbf{h}$ //h1)
\end{tabular}

From Table III, it is inferred that all the observed readings are found to be in accordance with the EFNARC guidelines.

\section{Compressive strength test}

Cubical specimens of size 150 X $150 \times 150 \mathrm{~mm}$ were casted, cured and tested to find out the compressive strength. Specimens were tested for both 7 days and 28 days. Two types of fibers namely crimped type fiber and Hook end type steel fibers were added and their respective strengths are tabulated in Table IV

Table IV : Compressive Strength of SCC with Steel Fibres

\begin{tabular}{|c|c|c|c|c|c|}
\hline & & Hore & & & \\
\hline \multirow[b]{2}{*}{ MIX } & \multirow{2}{*}{$\begin{array}{c}\text { FIBER } \\
\text { CONTENT } \\
\left(\mathrm{Kg} / \mathbf{m}^{3}\right)\end{array}$} & \multicolumn{2}{|c|}{$\begin{array}{c}\text { COMPRESSIVE } \\
\text { STRENGTH } \\
7 \text { DAYS } \\
\left(\mathrm{N} / \mathrm{mm}^{2}\right)\end{array}$} & \multicolumn{2}{|c|}{$\begin{array}{c}\text { COMPRESSIVE } \\
\text { STRENGTH } \\
28 \text { DAYS } \\
\left(\mathrm{N} / \mathrm{mm}^{2}\right)\end{array}$} \\
\hline & & $\begin{array}{c}\text { Crimped } \\
\text { end type } \\
\text { fiber }\end{array}$ & $\begin{array}{c}\text { Hooked } \\
\text { end type } \\
\text { fiber }\end{array}$ & $\begin{array}{l}\text { Crimpd } \\
\text { end } \\
\text { type } \\
\text { fiber }\end{array}$ & $\begin{array}{c}\text { Hooked } \\
\text { end } \\
\text { type } \\
\text { fiber }\end{array}$ \\
\hline SCC1 & 25 & 18.1 & 18.1 & 23.60 & 25.6 \\
\hline $\mathrm{SCC} 2$ & 40 & 25.3 & 25 & 29.26 & 30.5 \\
\hline $\mathrm{SCC} 3$ & 60 & 23.66 & 25.2 & 26.4 & 32.6 \\
\hline SCC4 & 70 & 23 & 25 & 27.5 & 30.46 \\
\hline
\end{tabular}

The variation of the strength of SCC with respect to the proportion of fiber and type of fiber could be well depicted from Figure 1 


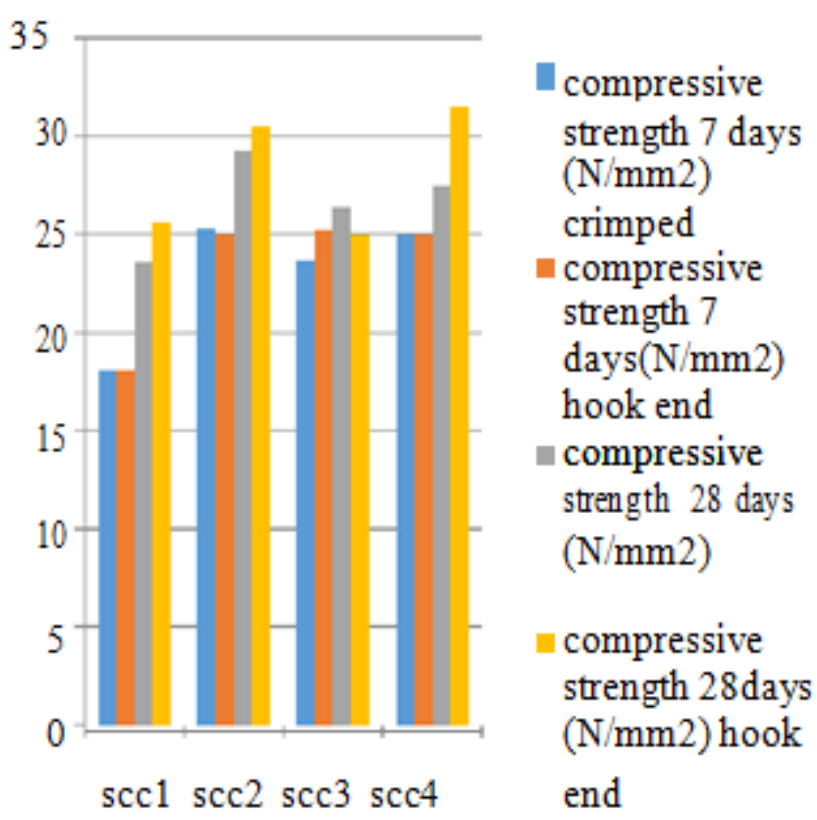

Fig 1 : Compressive Strength of SCC with Steel Fibres

From Figure 1 it is clear that about 80 percent of the strength was obtained in the seventh day itself. Also Hook end type fiber were found to yield more amount of strength when compared with the crimped type steel fiber. Also when the amount of fiber increases more than 1 percent the strength reduces.

$K$.Split tensile strength test

Cylindrical specimens of size 150 X $300 \mathrm{~mm}$ were casted, cured and tested at 7 and 28 days with both crimped type fibers and hook end type fibers and reading are tabulated in Table V

Table V : Split Tensile Strength of SCC with Steel Fibres

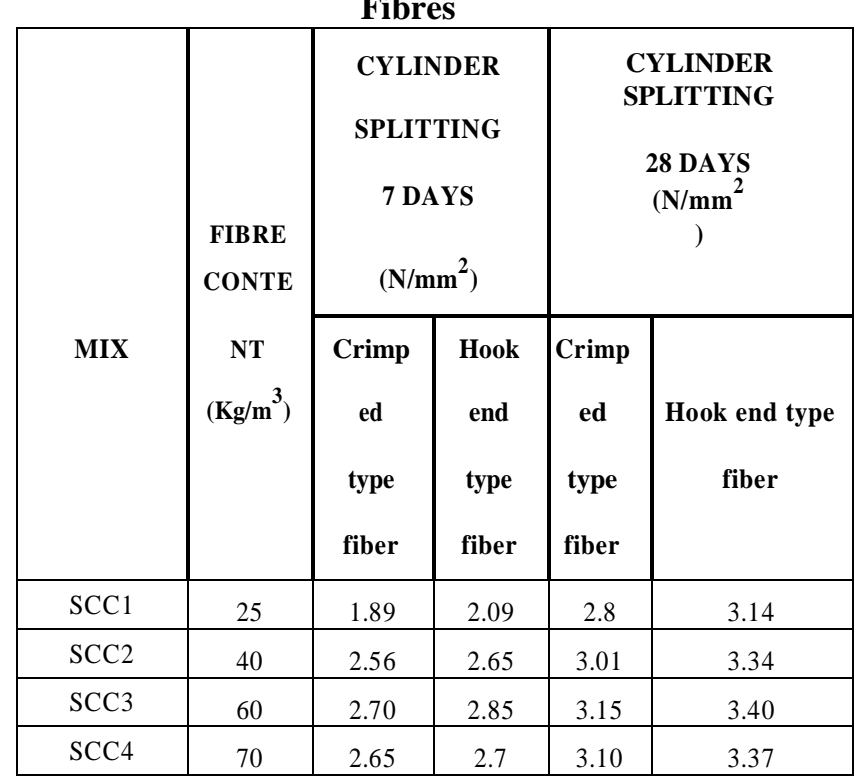

Figure 2 depicts the tensile strength attainment for various types of fibers in SCC more precisely

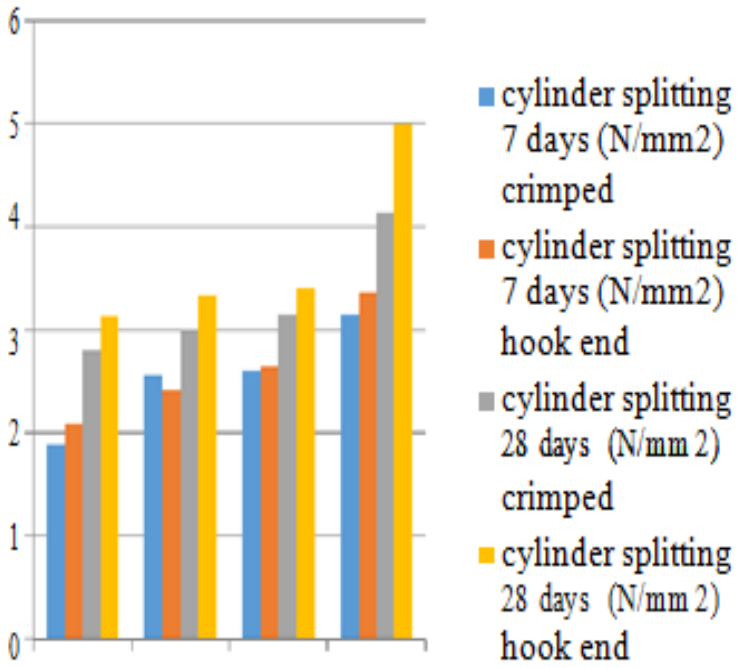

$\operatorname{scc} 1 \operatorname{scc} 2 \operatorname{scc} 3 \operatorname{scc} 4$

Fig .2 Cylinder Splitting Strength of SCC with Steel Fibres

From Table V and Figure .2 it is clear that the tensile strength of SCC increases with the increase in steel fiber till 1 percent and after that it decreases. Fibers with hook end type were found to increase the strength more than the crimped type.

\section{Conclusion}

From the above discussed detailed investigation, conclusions could be drawn as follows, Fiber reinforced Self compacting Concrete were found to perform well in all the engineering properties while being in good standing with the flow ability, filling ability and passing ability properties. Hooked end type of steel fiber were found to be advantageous than the crimped type steel fiber About 80 percent of the strength of fiber reinforced SCC could be attained at the end of 7 days itself. Hooked end steel fiber compressive strength of concrete is more than $(14.4 \%)$ the crimped fiber at $0.7 \%$ fiber content of concrete $(70 \mathrm{~kg} / \mathrm{m} 3)$.Hooked end steel fiber cylinder splitting strength of concrete is more than $(10.8 \%)$ the crimped fiber at fiber content of concrete $(70 \mathrm{~kg} / \mathrm{m} 3)$.Hooked end steel fiber cylinder compressive strength of concrete is more than $(10.52 \%)$ the crimped fiber at $0.7 \%$ fiber content of concrete $(70 \mathrm{~kg} / \mathrm{m} 3)$ Augmentation of fibers were found to be beneficial till 1 percent beyond which it decreases. Based on the above investigations, hooked end steel fibre is better than crimped steel fibre.

\section{REFERENCES}

1. Leemann. A, Loser. R, Münch. B, "Influence of cement type on ITZ porosity and Chloride resistance of self-compacting concrete", Cem. Concr. Compos. 32 (2010) 116-120 (2010)

2. Silva. Y, Robayo. R, Mattey. P, Delvasto. S, Obtaining a, "self-compacting concrete with finely ground coal slag" 35 (2015) 86-94.

3. Liu. M, "Self-compacting concrete with different levels of pulverized fuel ash" Constr. Build. Mater. 24 (2010) 1245-1252. (2010)

4. Sahmaran. M, Christianto. H. A, Yaman. I.O, "The effect of chemical admixtures and mineral additives on the properties of self-compacting mortars", Cement Concr. Compos. 28 (2006) 432-440. 
5. Filho. F.M.A., Barragán. B.E., Casas. J.R., "Hardened properties of self compacting concrete - a statistical approach" Constr. Build. Mater 24 (2010) 1608-1615.

6. Flower. D.J.M., Sanjayan J.G, "Green house gas emissions due to concrete manufacture", Int. J. LCA 12 (2007) 282-288

7. Chithambar Ganesh. A \& Muthukannan. M, "A Review Of Recent Developments In Geopolymer Concrete" International Journal of Engineering \& Technology 7 (4.5) (2018) 696-699

8. Chithambar Ganesh. A \& Muthukannan. M, Rajeswaran. M, Uma Shankar. T and Mari Selvam, "Comparative Study On The behaviour Of Geopolymer Concrete Using M-Sand and conventional concrete exposed to elevated temperature",International Journal of Civil Engineering And Technology (IJCIET), 9 (11) (2018), 981-989.

9. Bosiljkov, V.B.,"SCC mixes with poorly graded aggregate and high volume of limestone filler" Cem. Concr. Res., 33 (9):1279-1286. 2003.

10. European guidelines for "self compacting concrete, specification, production and use". EFNARC. 2005. May

11. Standard test method for "slump of hydraulic cement concrete", Annual Book of ASTM Standards, 1-8. ASTM C 143-03. 2003

12. Standard specifications for "chemical admixtures for concrete", Annual Book of ASTM Standards. ASTM C 494. 1992.

13. AmrS.El-Dieb, "Mechanical, durability \& microstructural characteristics ultra high strength SCC incorporating steel fiber", Materials and Design Vol.30(2009) 4286-4292

14. H. David et al. / Advances in Science, Technology and Engineering Systems Journal Vol. 4, No. 2,XX-YY (2019)

15. P.Dinakar, K.G.Babu, Manu Santhanam, "Durability properties of high volume fly ash self compacting concretes" Cement and Concrete Composites Vol.30(2008)880-886

16. Ilker BekirTopcu, MehmetCanbaz, "Effect of different fibers on the mechanical properties of concrete containing fly ash" Construction and Building Materials 21 (2007)1486-1491

17. Krishna Rao, Ravindra, "Steel fibre reinforced self compacting concrete Incorporating class f fly ash". Vol. 2(9), 2010, 4936-4943

18. Prof. D. B. Kulkarni Prof Mrs S N Patil, "Comparative Study of Effect of Sustained High Temperature

onstrength Properties of Self Compacting Concrete and Ordinary Conventional Concrete", International Journal of Engineering and Technology Vol.3 (2), 2011, 106-118

19. Rafat Siddique, "Properties of self compacting concrete containing class f fly ash" Materials and Design Vol 32 (2011) 1501-1507

20. T.SureshBabu, M.V.SeshagiriRao, D.RamaSesh, "Mechanical properties and stress - strain behavior of self compacting concrete with and without steel fibers", Asian journal of civil engineering (2008)457-472

21. Yining Ding, Cecilia Azevedo, Aguiar.J.B, Said Jalali, "Study on residual behavior and flexural toughness of Fibre cocktail reinforced self compacting high Performance concrete after exposure to high temperature", Construction and Building Materials(2011)

22. Norfolk, UK, "Specification and guidelines for self-compacting concrete", English edition. European Federation for Specialist Construction Chemicals and Concrete systems. EFNARC. February 2002R

23. Deeb, A. Ghanbari, B.L. Karihaloo, "Development of self-compacting high and ultra high performance concretes with and without steel fibres" Elsevier 5 November 2011,

\section{AUTHORS PROFILE}

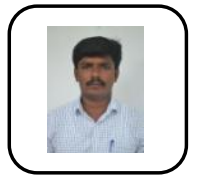

Mukilan K Completed his Master of Engineering in the field of Construction Engineering and Management in RVS Technical Campus, Coimbatore in the year of 2015 .He completed his Bachelor of Technology under Kalasalingam University in the year of 2012. He has more than five years of experience in teaching. He has published various papers in the reputed journals. His main thrust research areas are Construction management

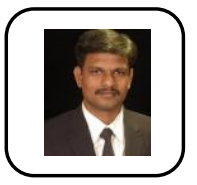

Ramesh Babu C completed his Ph.D. from IIT Chennai. He has more than ten years of experience in teaching and research. His areas of research includes pervious concrete, geo polymer concrete, and high volume fly ash concrete

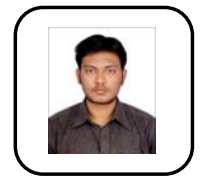

Chithambar Ganesh A completed his M.Tech in Structural Engineering in VIT University, Vellore in the year 2015. He completed his Bachelor of Engineering under Anna University in the year 2012. He is working as Assistant Professor in Department of Civil Engineering at Kalasalingam University, Tamilnadu, India. His main thrust research areas are Geopolymer concrete and Fiber reinforced concrete. 